\title{
Is Innovation a Second Order Construct: Clarifying the Formative and Reflective Measures of Innovation
}

\author{
Dr. Tahseen Arshi, A. \\ Director of Studies, FoBM \\ Majan University College
}

\begin{abstract}
The primary purpose of this study is to bring clarity to the measurement of innovation construct, particularly within corporate firms. Measures of innovation continue to be debated in academic literature and absence of universally accepted and valid quantitate scale of innovation can be attributed to lack of clarity of innovation measures. Academic research needs to increase the understanding of diverse conceptualization and operationalization of the innovation construct and its implications in research and practice. Drawing from corporate entrepreneurship and innovation literature, this study argues that innovation is a second order construct consisting of radical and incremental innovation degree and frequency, which are its reflective measures. It further argues that readiness for innovation is a formative measure and an antecedent to innovation. The study uses a dominantly quantitative approach and utilizes structural equation modelling to test the measures of innovation through first and second order measurement and structural models. The results of the study on a sample of Omani corporate firms indicate that measurement of innovation can better understood through both reflective and formative measures.
\end{abstract}

Key Words: Corporate entrepreneurship, radical innovation, incremental innovation, formative and reflective measures.

\section{INTRODUCTION}

Corporate entrepreneurship is closely associated with innovation. Some studies treat corporate entrepreneurship synonymous to innovation and argue that without innovation corporate entrepreneurship cannot be conceptualized. Burns (2016) citing Kuratko et al. (2015) pointed out that entrepreneurship and innovation are used interchangeably as the objective of corporate entrepreneurship is to achieve 'superior organizational performance' by promoting innovation at all levels of the organization. Since corporate entrepreneurship does not claim a rich pedigree of theoretical and empirical development, only few prominent models are proposed in the literature. Some of the prominent models are Entrepreneurial Management (Steven and Jarillo 1990), Entrepreneurial Intensity (Morris and Sexton 1996) Organizational Climate Models (Amabile, 1997, Isaksen and Ekvall, 2010) Entrepreneurial Architecture (Burns 2013), and Entrepreneurial Orientation (Lumpkin and Dess, 1996 and Covin and Slevin, 1991). These models treat innovation with prime importance but few have attempted to clarify the innovation construct. Entrepreneurial Orientation (EO) is a widely researched and cited construct of corporate entrepreneurship (Rauch et al. 2009) and Innovation is a key factor of $\mathrm{EO}$ along with four other factors namely risk taking, proactiveness, competitive aggressiveness and autonomy. The five factor model of EO has attracted considerable empirical attention (Parkman et al. 2012). The conceptualization of innovation dimension within EO as 'innovativeness' implies the ability of the organization to be 
innovative, rather than measures of innovation itself. A closer look at the original measures of innovation within EO indicated that these measures includes input measures, such as research and development, as well as output measures such as new products and services. This conceptualization of both input and output measures within innovation literature in general and EO literature in particular, requires empirical clarification and this study precisely aims to do so. According to Lumpkin and Dess (1996), innovativeness within the EO construct meant the 'willingness' of the firms to pursue new ideas and to explore and experiment with them with creativity.

\section{LITERATURE REVIEW}

Wales et al. (2013) and Covin et al. (2006) argued that entrepreneurial orientation is one of the most prominent and widely accepted constructs in the extant literature and without innovation entrepreneurship is difficult to conceptualize. Dess and Lumpkin (1996, p.49) observed that "without innovation other dimensions of EO have little or no value". It was observed that innovation drives all other EO dimensions. Yildiz (2014) citing Rutherford and Holt (2007) pointed out that innovation is an important force behind two of the most important functions of corporate entrepreneurship, which are strategic renewal and business venturing. Measurement of innovation continue to be an issue of interest in the literature and an unrestricted search on innovation yields thousands of results, but the lack of clarity of measurement of innovation persists.

\section{Innovation}

The literature on innovation is rich with abundance of definitions and explanations. Baregheh et al. (2009, p. 1324) reported that "there is no clear authoritative definition of innovation" and conceptualizations have varied over the last 40 years of research on innovation. Innovation was explained as "the proposal and generation of new ideas and commercial exploitation of its outcomes" (Tonnessen, 2005, p.195). Proctor (2014, p. 288) defined innovation as "practical application of new inventions into marketable products and services". Wang and Ahmed (2004, p.306) defined innovation as Organization's overall innovative capability is conceptualized as consisting of product, market, and process, behavioural and strategic innovativeness". The UK government white paper Innovation Nation (2007, p. 13) defined innovation as "Successful exploitation of new ideas". Sabarae (2010, p.6) concluded that "Innovation is not an isolated event but fruit of a process hence the concerns with assessing not just a simple result (number of innovations), but rather the maturity of the process." Finally, Wang et al., $(2015, p$. 65) defined as innovation as Entrepreneurial orientation (EO) is seen as a significant driver of firms' innovation capability. The last two definitions of innovation is interesting as it clearly implies that innovation is a process comprising of inputs and outputs (key words being 'processes' and 'driver'). Innovative inputs are essential for 'innovative outputs' to be exploited in the 'market' as defined by Tonnesen (2005, p.196) 'marketable products and services' as explained by Proctor (2014, p. 288). Vasconcellos and Marx (2011), Forsman (2011) and Sebrae and Texeria (2010) all argued that innovation is a process comprising of input and output factors. Therefore, 'readiness for innovation' as input factor, should precede innovation.

\section{Readiness for innovation}

The literature on innovation, particularly within the context of EO indicates that innovation involves a series of processes ranging from input to output stages. Amabile et al. (1997) and Isaksen and Ekvall (2010) laid emphasis on organizational climate and resources that promotes innovation. Bessant (2005) pointed toward importance of capabilities and mind set for innovation to occur, while Shah et al. (2011) and Dyer et al. (2011) focused on resources and networking to promote innovation. These studies pointed out that certain conditions or inputs for innovation are required before innovation outputs can be achieved. It implies two 
prepositions. One, that there are certain antecedents for innovation to happen. Second, these antecedents causes innovation to happen and these are not measures of innovation but rather causes of innovation. Measures of innovation are evident in the 'market' (Tonnesen, 2005) and radical and incremental innovation have been proposed in the literature as measures of this innovation (Bessant and Tidd, 2011).

\section{Measures of Innovation: Radical Innovation}

Assink (2006, p. 217) defined radical innovation as "a successfully exploited radical new product, process, or concept that significantly transforms the demand and needs of an existing market or industry, disrupts its former key players and creates whole new business practices or markets with significant societal impact." This definition is quite comprehensive as it implies a number of measures of radical innovation. Radical innovation measures comprises of radically new products and services, disruptions to the market and competition and changes in customer behaviour and demand patterns. Goffin and Mitchell (2010) and Prahlad and Mashelkar (2010) argued that size or degree of impact is the primary source of competitive advantage derived from radical innovation.

\section{Measures of Innovation: Incremental innovation}

Jha et al. (1996, p. 22) defined continuous incremental improvement as "a collection of activities that constitute a process intended to achieve performance improvement".Goffin and Mitchell (2010) and Bessant (2005) explained that incremental Innovation involves improvement of existing products and services. Incremental innovation is usually safe (considering lower risks), less expensive and can be achieved in reasonably short time lines and hence is more frequent in occurrence (Bessant and Tidd, 2011). Incremental innovation does not impact the market and competition in a major way and is not disruptive, unlike radical innovation. The primary competitive advantage of incremental innovation comes from its frequency, which enhances the sustainability of products and services in the market (Bessant and Tidd, 2011).

\section{RESEARCH GAP}

The discussion in the literature indicates that there is lack of clarity on measures of Innovation. Despite the wealth of research and interest in innovation construct, there are two major gaps in the literature related to the innovation construct. First, there is no universally accepted definition or explanation of innovation construct and there has been varied levels of conceptualization and operationalization of the innovation construct. The literature has interchangeably used the measures of innovation with measures of 'readiness for innovation' (RTI). The first research gap has given rise to the second, which is, the literature is devoid of universally accepted quantitative scale of innovation. Further, amongst the proposed models of innovation in the literature most of the models treat innovation as a first order construct without throwing much light on the measures and nature of the construct. This calls for rigorous research and empirical evidences that can clarify the measurement of innovation. Based on the research gaps the following research model (figure 1) is developed and associated hypotheses are framed. 


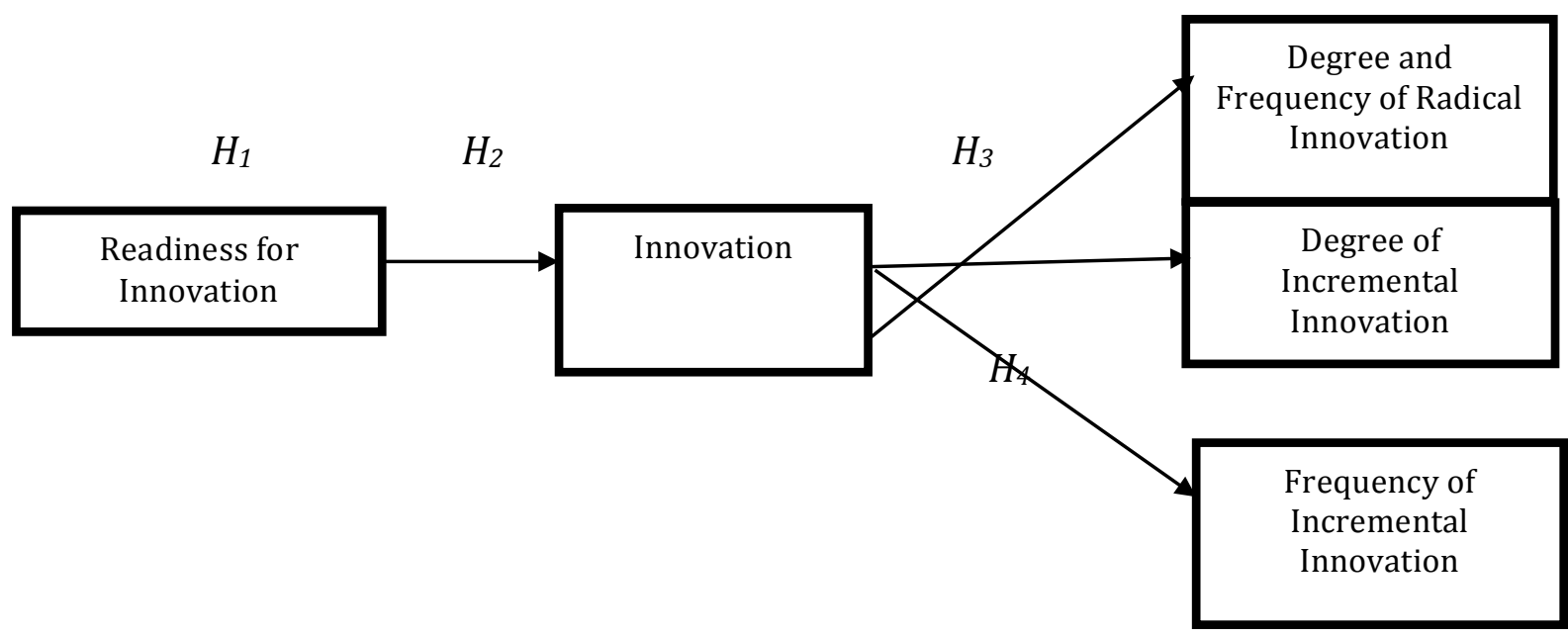

Figure 1: Research Model

The research model is presented as per the hypothesized relationships in this study. Diamantopoulos and Siguaw (2006) are of the view that empirical studies should clarify the hypothesized relationship, particularly clarifying whether the measures are studied formatively or reflectively. Hardin et al. (2008) explained that if the measures are conceptualized reflectively, variation in a construct leads to variation in its measures. On the hand, formative measures indicate that the variation in the measures have a causal effect on the construct. The first half of the research model above represents the causal relationship (formative measure) between readiness for innovation (RTI) and innovation which is, an output of the organization. The second part of the research model represents the reflective measures where the degree and frequency of innovation are quantitative measures of innovation construct. Degree and frequency of incremental innovation is treated as separate construct as the literature suggested that frequency is a key measure of innovation and is therefore more associated with incremental innovation rather than radical innovation.

\section{$H_{1}$ : Readiness for innovation is an antecedent to innovation}

$\mathrm{H}_{2}$ : Readiness for innovation has a positive impact on innovation

$H_{3}$ : Innovation is a second order construct with radical innovation degree and frequency as its appropriate measures.

$H_{4}$ : Incremental Innovation frequency and degree are appropriate measures of incremental innovation at the first order and innovation construct at the second order.

\section{METHODOLOGY}

Epistemologically this study aims to contribute towards measurement of innovation construct and therefore, positivism and realist approach was more suited to the study. Ontologically an objectivist approach is the correct philosophical positioning of this research as the participants had little control over the measurement of the construct (Saunders, 2010). Since this study adopted a positivist and realist approach and follows a deductive approach, all the measures were adopted from the literature using relevant theoretical frameworks (Fisher, 2004). Quantitative research strategies were the dominant research strategy, although its limitations are well recognized. A realist approach enabled to test relationship between variables as well as test hypotheses. Measurement, reliability, causality, and validity, were key considerations 
and were the metrics used in this research to assess its rigor and robustness as well as to infer its appropriateness for generalisability.

\section{Sample unit of analysis}

Ireland (2009) suggested that corporate entrepreneurship and innovation should be studied at 'organizational members' level. Based on judgement sampling middle level managers were chosen as suggested by Kuratko et al. (2015). Additionally, as per the recommendations of Covin et al. (2006), top managers were also chosen as they (ibid) argued that top managers play an important role in promoting innovation at the corporate level. A sample size of 400 managers was decided based on Yamane's formula. One middle or top manager was chosen from each organization representing different sectors of Omani corporate sector.

\section{Measures}

The measures of readiness for innovation was derived from the original EO scale (Covin and Slevin 1989) EO Modified Scale (Morris and Sexton, 1996), while some were adopted by studies that modified and tested the EO scale in different research settings such as Morris et al. (2011) and Liao et al. (2005). 'Readiness for innovation' measures were also influenced by Innovation Capacity Model (Hurley and Hult, 1998), Innovation Capability-Rigidity Paradox (Atuahene-Gima, 2005) and Organizational Climate Model (Amabile, 1997). The measures for innovation construct were derived from various models which includes entrepreneurial intensity (Morris and Kuratko, 2002); (Tahseen, 2012); Innovation Ambition Matrix (Nagji and Tuff, 2012); incremental and radical innovation studies by Bessant and Tidd (2011) and Innovation intensity (Burns, 2013). The description of measures are shown in appendix 2.

\section{RESULTS}

Before analysing the data, the reliability and robustness of data was checked through various statistical tests. The results showed satisfactory levels of reliability with Cronbach Alpha scores $>.7$ as suggested by Saunders (2010).

Table 1: Cronbach Alpha ( $\alpha$ ) coefficients for reliability of the factors

\begin{tabular}{|c|c|c|c|}
\hline Factors & Cronbach's Alpha & Number of Items & Total Cases \\
\hline Readiness for innovation & .779 & 6 & 404 \\
\hline Radical Innovation degree and frequency & .786 & 9 & 404 \\
\hline Incremental Innovation Degree & .820 & 5 & 404 \\
\hline Incremental Innovation Frequency & .787 & 3 & 404 \\
\hline
\end{tabular}

Tests of homoscedasticity indicates that the sample across various sectors was homogeneous (Levene Statistic >.05 and single column Tukey HSD) on all control measures such as position, experience and education. Normality of data was checked through Kolmogorov Smirnov and Shapiro Wilks (test values $>.000$ ) which showed that that the data was derived from a normally distributed sample. There was no evidence of multi- collinearity (VIF <.2). After confirming the robustness of data, the measures were subjected to exploratory factor analysis involving Principal Components Analysis with Promax Rotation and Kaiser Normalization as suggested by Kline (2011). The KMO scores, which was quite good showed that the data is fit enough to conduct factor analysis and structural equation modelling tests.

Exploratory factor analysis (EFA) was conducted to test the factorial structure of 'readiness for innovation' (RTI) construct and 'innovation' construct. The patterns matrix showing the factorial structures is shown in Appendix 1. The measures loaded satisfactorily on the RTI construct $(>.40)$. The measures also loaded satisfactorily $(>.40)$ onto three factors of 
innovation construct namely radical innovation degree and frequency, incremental innovation degree and incremental innovation frequency.

Table 2: KMO and Bartlett's Tests

\begin{tabular}{|l|l|r|}
\hline \multicolumn{3}{|c|}{ KMO and Bartlett's Test } \\
\hline Kaiser-Meyer-Olkin Measure of Sampling Adequacy. & .855 \\
\hline \multirow{2}{*}{ Bartlett's Test of Sphericity } & Approx. Chi-Square & 3662.002 \\
\cline { 2 - 3 } & $\mathrm{df}$ & 253 \\
\cline { 2 - 3 } & Sig. & .000 \\
\hline
\end{tabular}

Structure Equation Modelling (SEM) was further applied as it is powerful tool to test the hypotheses. SEM is a combination of factor analysis and regression and indicates both formative and reflective modelling through path diagrams (Tabachnik and Fidel, 2007). Further, modelling interactions, non-linearity, correlated independents, correlated errors and error terms are accounted for in SEM analysis (Gaskin, 2012). In order to test the factorial structure of innovation construct which comprises of radical and incremental innovation degree and frequency, a measurement model was developed. The results showed that radical innovation degree and frequency is a single factor, while incremental innovation degree and frequency split into two factors. The results are shown in figure 2 below.

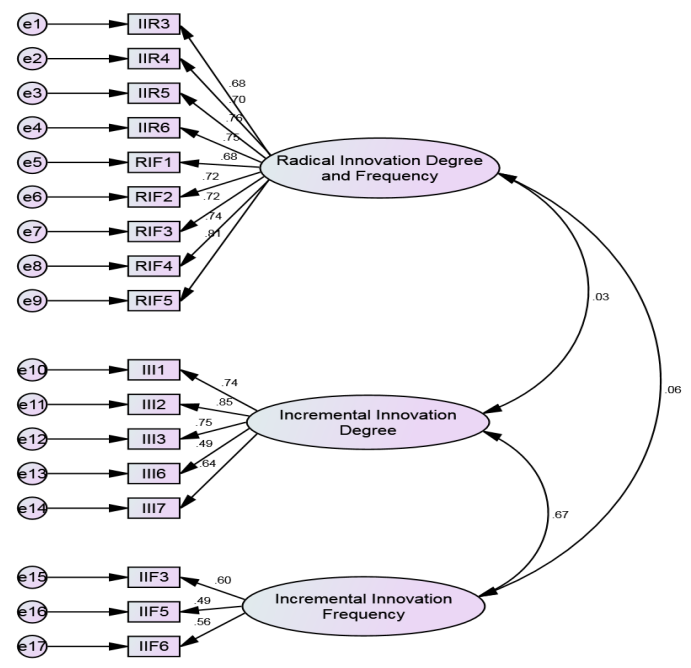

CMINDF 1.867 GFI .997 AGFI .964 CFI.995 RMSEA .038

Figure 2: Measurement Model 1 testing the dimensions of innovation construct

(Labels: IIR-Radical innovation degree, RIF- Radical innovation frequency III- Incremental innovation degree, IIFIncremental innovation frequency)

The fit indices in the measurement model 1 were strong indicating a good model fit. The factor loadings were satisfactory $(>.40, \mathrm{p}<.001)$ and the measures loaded on their respective factors as conceptualized and operationalized. The covariance scores were low (.03 and .06) indicating discriminant validity, except between incremental innovation degree and frequency. Therefore, there was a need to further check whether the factors belonged to the same construct or two separate constructs. Therefore, in order to test whether incremental innovation degree and incremental innovation frequency were indeed measures of incremental innovation, a second order measurement model was tested and the results are shown in figure 3 below. 


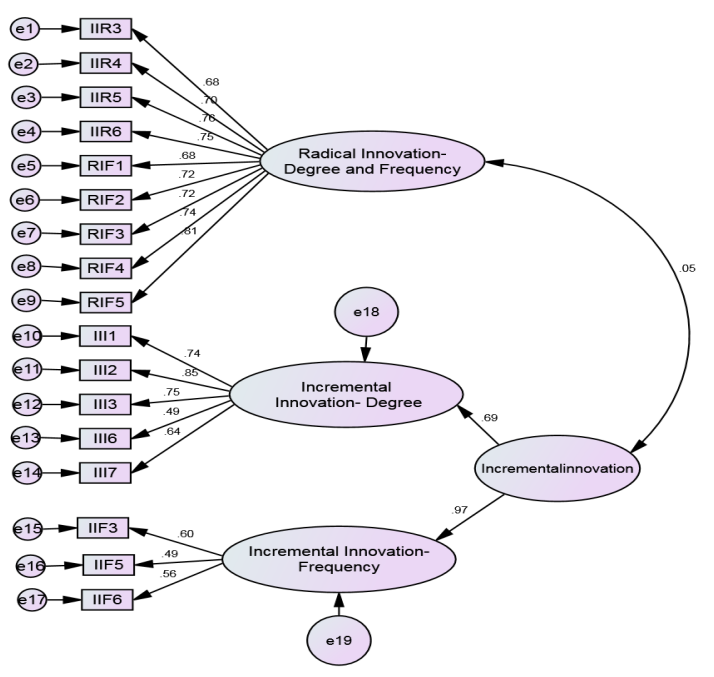

CMINDF 1.951 GFI .992 AGFI .951 CFI.992 RMSEA .041

Figure 3: Measurement Model 2 for Incremental innovation degree and frequency

(Labels: IIR-Radical innovation degree, RIF- Radical innovation frequency III- Incremental innovation degree, IIFIncremental innovation frequency)

The fit indices in the measurement model 2 indicated good fit of data showing good measurement of fit, as suggested by Kline (2011). The measurement model 2 shows that radical and incremental innovation degree and frequency as appropriate measures of innovation. The results in the two measurement models indicate that $H_{1}$ is supported positively and significantly. At the same time, the measurement model 2 showed that incremental innovation degree and frequency are indeed measures of the incremental innovation construct and second order testing showed factor loadings of .69 and $.97(\mathrm{p}<.05)$ indicating that the measures loaded satisfactorily on incremental innovation construct. The factor loadings on all measures (>.40) indicated convergent validity, while low covariance scores between factors (.05) indicated discriminant validity.

Finally, the research model was tested through the structural model and the results are shown in figure 4. Based on the cut off criteria (>.40), as suggested by Tabachnik and Fidel (2007), all items validated in the measurement model were retained in the SEM model. Only the labels of measures were changed for clarity. Both the factor loading and coefficient values were good enough to judge the hypotheses. All the fit indices were satisfactory as shown in figure 4 below.

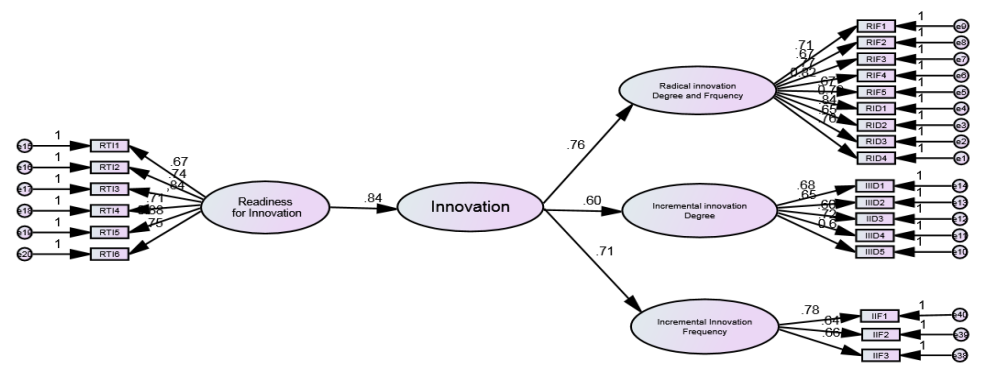

CMINDF 1.979 GFI .982 AGFI .911 CFI.982 RMSEA .048

Figure 4: Complete SEM Model showing formative and reflective measures of innovation at the first and second order

(Labels: RTI - Ready to innovate, RID-Radical innovation degree, RIF- Radical innovation frequency IID- Incremental innovation degree, IIF- Incremental innovation frequency) 
The complete SEM model shows that $H_{2}$ is well supported positively and significantly. The complete SEM model showed that readiness for innovation (RTI) dimension significantly and positively impacts innovation output reflected through the radical and incremental innovation (Path coefficient value of .84 $\mathrm{p}<.001$ ). Therefore, structural model indicates that RTI is instrumental in promoting innovation. Based on the findings $H_{3}$ is supported positively and significantly as radical innovation degree and frequency (path coefficient value $.76, p<.001$ ) were found to be reflective measures of innovation construct. Further, based on the findings $H_{4}$ is supported positively and significantly as incremental innovation degree (path coefficient value $.60, \mathrm{p}<.001$ ) and incremental innovation frequency (path coefficient value .71, $\mathrm{p}<.001$ ) were found to be reflective measures of innovation.

\section{DISCUSSION}

The findings confirmed that readiness for innovation is an antecedent to innovation. An organization should be first ready to innovate before innovation outputs can be achieved. Rodrigues et al. (2010) therefore argued that innovation is the result of innovativeness. The same views resonate with Kamaruddeen et al. (2011) and Mbiziet al. (2013) who argued that innovativeness is about developing the organization's capability to innovate. Innovativeness or readiness for innovation involves creating conditions, climate, resources and capabilities for innovation. Without the necessary resources and capabilities innovation is difficult to achieve, even if the organization is committed to realize its innovation dream. Garcia and Calantone (2002, p. 113) argued that "propensity for innovation" is important condition, while Lumpkin and Dess (1996, p. 142) argued that "willingness for innovation" is an important condition for innovation to take place. Baregeheh et al. (2009) opined that innovativeness is often mixed up with measures of innovation. Innovativeness or readiness for innovation is formative measure that promotes innovation, while the measures of innovation are reflective measures, which can be utilized in development of quantitative scales of innovation. The six formative measures included in this study for readiness for innovation factor revolved around creating an organizational climate where ideas are encouraged, recognized and rewarded, resources and capabilities are created through external partnership and creation of new venture units. On the other hand, reflective measures of innovation at the second order revolved around radical and incremental innovation degree and frequency which is evident in the market.

Measures of radical innovation at the first order included radical new products and services, development of radical technologies (Vaughan, 2013), creation of new target market, changes in customer and competitive behaviour (Jansen et al. 2006 and Norman and Verganti, 2014). Radical innovation focuses on competency destroying and not letting firms slip into comfort zones. Existing competencies may be beneficial to firm in the short run, but in the long run these competencies can in fact become core rigidities. Radical innovation is more associated with degree and impact rather than frequency. Since incremental innovation requires lower research and development intensity, incremental innovation is more frequent than radical innovation. Banu and Grant (2011) pointed out that radical innovation requires higher research and development intensity and is more risky and hence have lower frequencies.

Measures of incremental innovation degree at the first order revolved around modifications and improvement in existing products and services, listening to customer feedback (Martin, 2011), satisfying existing customers (Arnold et al, 2011) and penetration of existing target markets (Ashish et al, 2009). While radical innovation was competency destroying, incremental innovation is competency enhancing so that continuous improvements can take place. Therefore, incremental innovation frequency become important. Chen and Bau-Guang 
(2012) had emphasised the need for measuring frequency of innovation, which accumulated over a period of time, can provide firms with competitive advantage.

\section{CONCLUSION}

The findings of this study is based on sound empirical evidence and contributes to better understanding of formative and reflective measures of innovation. Innovation in corporate firms is very important not only for competitive advantage but also for its survival. Academicians, researchers and practitioners should have a better understanding of innovation measures so that the resources, capabilities and organizational climate can be aligned with its innovation goals which may be targeted either towards radical and incremental innovation. It is implied that resources, capabilities and organizational climate for radical innovation will be different, than for incremental innovation. Readiness for innovation can be either for radical or incremental innovation. There is further debate in the literature, but beyond the scope of this study, to discuss the interactions between the two types of innovation measures. However, it is important to note that the conditions of 'readiness for innovation' must be created before innovation is expected. The measures of incremental innovation were opposite to measures for radical innovation as both try to leverage on different philosophies. While radical innovation is disruptive, incremental innovation is sustaining. A better understanding of both formative and reflective measures of innovation can help firms to understand and implement innovation strategies in their firms. The abstract and many faces of innovation can be better understood through the findings of this study and it is expected that this study has in many ways improved the understanding of measures of innovation construct. However, the study has its limitations. The sample represents wide variety of sectors, but every sector could not be included in the study. Further, qualitative and in-depth investigations could not be conducted in this study, which could have further clarified the measures with more contextual understanding of the measures. These are therefore, future research directions. At the same time, these hypotheses and the research model can be tested in different research settings so that both generalisability and transferability of the findings can be established and enhanced.

\section{References}

Amabile, T.M. (1997) Motivating creativity in organizations: on doing what you love and loving what you do. California Management Review, 40(1), 39-58.

Arnold, T.J., Fang, E. and Palmatier, W.J. (2011) The effect of customer retention and acquisition orientations on firms incremental and radical innovation performance. Journal of Marketing Academy Science, 39, $237-251$.

Ashish, S., Gareth, J. and Gerard, T. (2009) Functional Regression: A New Model for Predicting Market Penetration of New Products. Marketing Science, 28(1), 194-196.

Assink, M. (2006) Inhibitors of disruptive innovation capability: a conceptual model. European Journal of Innovation Management, 9(12), 215-233.

Atuahene-Gima, K. (2005) Resolving the Capability- Rigidity Paradox in New Product Innovation. The Journal of Marketing, 69(October), 61-83.

Banu, G. and Grant, M. (2011) Innovation Speed and Radicalness: Are they inversely related? Management Decision, 49(4), 533-547.

Baregheh, A., Rowley, J. and Sambrook, S. (2009) Towards a multidisciplinary definition of innovation. Management Decision, 47(8), 1323-1339.

Bessant, J. (2005) Enabling continuous and discontinuous innovation: Learning from the private sector. Public Money \& Management, 25(1), 35-42.

Bessant, J. and Tidd, J. (2011) Innovation and Entrepreneurship (2nd Ed.). Sussex, UK: John Wiley and Sons.

Burns, P. (2013) Corporate Entrepreneurship: Building an entrepreneurial organization, London: Palgrave Macmillan. 
Arshi, A. T. (2017). Is Innovation a Second Order Construct: Clarifying the Formative and Reflective Measures of Innovation. Archives of Business Research, 5(2), 1-13.

Chen, J., Sawhney, M. and Neubaum, D.O. (2013) Customer-Oriented Innovation and Firm Performance. Social Science Research Network [Online]. DOI: 10.2139/ssrn.2178114.

Chen, S.-T. and Bau-Guang, C. (2012) The Effects of Absorptive Capacity and Decision Speed on Organizational Innovation: A Study of Organizational Structure as an Antecedent Variable. Contemporary Management Research, 8(1), 27-50.

Covin, J.G. and Slevin, D.P. (1991) A conceptual model of entrepreneurship as firm behaviour. Entrepreneurship Theory and Practice, 16 (1), 7-25.

Covin, J.G., Green, K.M. and Slevin, D.P. (2006) Strategic process effects on the entrepreneurial orientation - sales growth rate relationships. Entrepreneurship Theory and Practice, 30(1), 57-81.

Dess, G.G. and Lumpkin, G.T. (2005) The role of entrepreneurial orientation in stimulating effective corporate entrepreneurship. Academy of Management Executive, 19(1), 147-156.

Diamantopoulos, A., \& Siguaw, J. A. (2006) Formative versus reflective indicators in organizational measure development: A comparison and empirical illustration. British Journal of Management, 17, 263-282.

Dyer, J. Gregersen, H. and Christensen, C.M. (2011) The DNA of disruptive innovator: mastering five skills of disruptive innovators. Boston, MA: Harvard Business Publishing.

Forsman, H. (2011) Innovation capacity and innovation development in small enterprises: a comparison between the manufacturing and service sectors. Research Policy, 40, 739-750.

Fisher, C. (2004) Writing Research dissertations for Business Students. London: Prentice Hall.

Gaskin, J. (2012) 'Model fit again'. Gaskination's Statswiki, Available at: http://statswiki.kolobkreations.com, retrieved on 20th January 2015.

Garcia, R. and Calantone, R. (2002) A critical look at technological innovation typology and innovativeness terminology: a literature review. Journal of Product Innovation Management, 19(2), 110-132.

Goffin, K. and Mitchell, R. (2010) Innovation Management. London: Palgrave Macmillan.

Hardin, A. M. Chang, C. and Fuller, M.A. (2008) Formative versus reflective measurement: comment on Marakas, Johnson and Clay (2007). Journal of Association of Information Systems, 9(9), 519-534.

Holt, D.T., Armenakis, A.A., Feild, H.S. and Harris, S.G. (2007) Readiness for organizational change: The systematic development of a scale. The Journal of Applied Behavioral Science, 43(2), 232-255.

Innovation Nation (2008) The UK government white paper on innovation, a report by the Secretary of State for Innovation, Universities and Skills, London.

Ireland, R.D., Kuratko, D.F. and Morris, H. (2006) A health audit for corporate entrepreneurship: Innovation at all levels. Journal of Business Strategy, 27(91), 10-17.

Isaken, S. G. and Ekvall, G. (2010) Managing for innovation: The two faces of tension in creative climates. Creativity and Innovation Management, 19, 73-88.

Jansen, J.J.P., Van Den Bosch, F.A.J. and Volberda, H.W. (2006) Exploratory innovation, exploitative innovation, and performance: Effects of organizational antecedents and environmental moderators. Management Science, 52(11), 16-61.

Hurley, R.F. and Hult, G.T.M. (1998) Innovation, market orientation, and organizational learning: an integration and empirical examination. The Journal of Marketing, 62(1), 42-54.

Jha, S., Michela, J. and Noori, H. (1996) The dynamics of continuous improvement: aligning organizational attributes and activities for quality and productivity. International Journal of Quality Science, 1(1), 19-47.

Kamaruddeen, A.M., Yusof, N.A. and Said, I. (2011) Assessing the innovativeness of housing developers in Malaysia, International Journal of Academic Research, 3(3), 178-183.

Kline, R.B. (2011) Principles and Practice of Structural Equation Modeling. (3rd Ed.), NY: Guilford Press.

Kuratko, D.F., Morris, M.H. and Schindehutte, M. (2015) Understanding the dynamics of entrepreneurship through framework approaches. Small Business Economics, 45(1), 1-13. 
Lumpkin, G.T. and Dess, G.G. (1996) Clarifying the Entrepreneurial Orientation Construct and linking it to Performance. The Academy of Management Review, 21(1), 135-172.

Lumpkin, G.T. and Dess, G.G. (2003) Linking two dimensions of entrepreneurial orientation to firm performance: The moderating role of environment and industry life cycle. Journal of Business Venturing, 19, 429-451.

Martin, R.L. (2011) The innovation catalysts. Boston, MA: Harvard Business School Publishing.

Mbizi, R., Hove, L., Thondhlana, A. and Kakava, N. (2013) Innovation in SMEs: A review of its role to organizational performance and SMEs operations sustainability. Interdisciplinary Journal of Contemporary Research in Business, $4(11), 370-389$.

Morris, M.H and Sexton, D.L. (1996) The concept of entrepreneurial intensity: Implications for company performance. Journal of Business Research, 36(1), 5-13.

Morris, M.H. and Kuratko, D.F. (2002) Corporate Entrepreneurship. Fort Worth, TX: Harcourt College Publishers.

Morris, M.H., Kuratko, D.F. and Covin, J.G. (2011) Corporate Entrepreneurship and Innovation. Mason, OH: Thomson South-Western.

Nagji, B. and Tuff, G. (2012) Managing your innovation portfolio. Harvard Business Review, May. Available at: https://hbr.org/2012/05/managing-your-innovation-portfolio

Norman, D.A. and Verganti, R. (2014) Incremental and radical innovation: Design research versus technology and meaning change. Design Issues, 30(1), 78-96.

Parkman, I.D., Holloway, S.S. and Sebastiao, H. (2012) Creative industries: aligning entrepreneurial orientation and innovation capacity. Journal of Research in Marketing and Entrepreneurship, 14(1), 95-114.

Prahalad, C.K. and Mashelkar, R.A. (2010) Innovation's Holy Grail. Harvard Business Review, July-August. Available at: https://hbr.org/2010/07/innovations-holy-grail

Proctor, T. (2014) Creative Problem Solving for Managers: Developing Skills for Decision Making and Innovation. New York Routledge.

Rauch, A., Wiklund, J., Lumpkin, G.T. and Frese, M. (2009) Entrepreneurial Orientation and Business Performance: An Assessment of Past Research and Suggestions for the Future. Entrepreneurship: Theory \& Practice, 33(3), 761787.

Rutherford, M.W. and Holt, D.T. (2007) Corporate entrepreneurship: An empirical look at the innovativeness dimension and its antecedents. Journal of Organizational Change Management, 20(3), 429-446.

Saunders, M., Lewis, P. and Thornhill, A. (2010) Research Methods for Business Students. London: Pitman Publication.

Sebrae, ADA, S.N. and Teixeria, R.M. (2010) measurement of the degree of innovation in micro and small enterprises: a study of textile business chain in Sergipe, RAI, 8 (3), 6-25

Tabachnik, B.G. and Fidell, L.S. (2007) Using Multivariate Statistics. London: Pearson International Education.

Tahseen, A. (2012) Entrepreneurial Intensity in the Corporate Sector in Oman: The Elusive Search Creativity and Innovation. International Business Research, 5(9), 171-183.

Tonnessen, T. (2005) Continuous innovation through companywide employee participation. TQM Magazine, 17(2), 195-207.

Stevenson, H. H. and J. C. Jarillo (1990) A paradigm of entrepreneurship: Entrepreneurial Management. Strategic Management Journal, 11, 17-27.

Shah, C.M., Ortt, J.R. and Scholten, V. (2011) Building a Radical Innovation Mechanism at Large Firms, World Scientific Publishing, Social Science Research Network [Online].

Vasconcellos, L.H.R. and Marx, R. (2011) Como ocorrem as inovações em serviços? Um estudo exploratório de empresas no Brasil. Gestão \& Produção, 18(3), 443-460.

Vaughan, J. (2013) Defining Technological Innovation. Library Technology Reports, 49(7), 10-46.

Wales, W.J., Gupta, V.K. and Mousa, F. (2013) Empirical Research on entrepreneurial orientation: an assessment and suggestions for future research. International Small Business Journal, 31(4), 357-383. 
Arshi, A. T. (2017). Is Innovation a Second Order Construct: Clarifying the Formative and Reflective Measures of Innovation. Archives of Business Research, 5(2), 1-13.

Wang, K.Y., Hermens, A., Huang, K. and Chelliah J. (2015) Entrepreneurial Orientation and Organizational Learning on SMEs' Innovation. International Journal of Organizational Innovation (Online), 7(3), 65-75.

Yildiz, M.L. (2014) The effects of organizational culture on corporate entrepreneurship. International Journal of Business and Social Science, 5(2), 35-44.

\section{Appendix 1: Results of EFA}

\begin{tabular}{|c|c|c|c|c|}
\hline \multicolumn{5}{|c|}{ Pattern Matrix ${ }^{a}$} \\
\hline & \multicolumn{4}{|c|}{ Component } \\
\hline & 1 & 2 & 3 & 4 \\
\hline EORI1 & & & .669 & \\
\hline EORI2 & & & .778 & \\
\hline EORI3 & & & 697 & \\
\hline EORI4 & & & .686 & \\
\hline EORI5 & & & .657 & \\
\hline EORI6 & & & .646 & \\
\hline III1 & & .731 & & \\
\hline III2 & & .857 & & \\
\hline III3 & & .787 & & \\
\hline III6 & & .675 & & \\
\hline III7 & & .716 & & \\
\hline IIF3 & & & & .559 \\
\hline IIF5 & & & & .763 \\
\hline IIF6 & & & & .782 \\
\hline IIR3 & .728 & & & \\
\hline IIR4 & .751 & & & \\
\hline IIR5 & .798 & & & \\
\hline IIR6 & .774 & & & \\
\hline RIF1 & .731 & & & \\
\hline RIF2 & .752 & & & \\
\hline RIF3 & .759 & & & \\
\hline RIF4 & .768 & & & \\
\hline RIF5 & .824 & & & \\
\hline
\end{tabular}

Extraction Method: Principal Component Analysis.

Rotation Method: Promax with Kaiser Normalization.

a. Rotation converged in 5 iterations. 
Appendix 2: Description of Measures

Readiness for Innovation

\begin{tabular}{|l|l|}
\hline RTI2 & An organizational culture of creativity and innovation is evident \\
\hline RTI2 & The leaders in my organization actively seeks and rewards innovative ideas \\
\hline RTI3 & We get time for learning and innovation \\
\hline RTI4 & $\begin{array}{l}\text { new competencies are developed in my organization even if the existing ones } \\
\text { are effective }\end{array}$ \\
\hline RT5 & $\begin{array}{l}\text { Venture units in my organization are focused on development of new products } \\
\text { and services }\end{array}$ \\
\hline RTI6 & $\begin{array}{l}\text { My organization is open to sourcing of ideas from shared forums and } \\
\text { professional groups }\end{array}$ \\
\hline
\end{tabular}

\section{Radical Innovation Degree and Frequency}

RID1 My organization finds and develops new target markets

RIF1 The frequency with which my organization has found or created new target markets has been higher over the last two years

RID2 My organization continuously shapes and modifies customer behaviours

RIF2 The frequency with which my organization has influenced customers' behaviours has been higher over the last two years

RID3 My organization introduces new products, services and processes, which are radically different from existing products and services in the market

RIF3 The frequency of introduction of radically different product and services in my organization has been higher over the last two years

RID4 My organization has utilized radically new technologies in our products, services and processes

RIF4 The number of times my organization has utilized latest technologies in our products, services and processes has been higher over last two years

RID5 My organization has been able to change the industry dynamics through its new product/ service

\section{Incremental Innovation Degree and Frequency}

\begin{tabular}{|l|l|}
\hline IID1 & My organization has considerably penetrated the markets in which it operates \\
\hline IIF1 & $\begin{array}{l}\text { The frequency with which my organization has penetrated existing target } \\
\text { markets has been higher over the last two years }\end{array}$ \\
\hline IID2 & My organization continuously removes deficiencies from products and services \\
\hline IIF2 & $\begin{array}{l}\text { The frequency of product and/or service improvements in my organization has } \\
\text { been higher over the last two years }\end{array}$ \\
\hline IID3 & The innovation in my organization is aimed at retaining existing customers \\
\hline IID4 & My organization makes improvements to the operational processes \\
\hline IIF3 & $\begin{array}{l}\text { The frequency with which my organization has met the demands of its } \\
\text { customers has been higher over the last two years }\end{array}$ \\
\hline IID5 & $\begin{array}{l}\text { My organization takes feedback from customers and suppliers to understand } \\
\text { industry trends }\end{array}$ \\
\hline
\end{tabular}

